\title{
Intercultural communication and success in business
}

\author{
Svetlana Alekseevna Dubinko ${ }^{{ }^{*}}$, Irina Iosifovna $\mathrm{Klimova}^{2}$, Lizaveta Alehauna \\ Dubinka-Hushcha $^{3}$, and Galina Vladimirovna Klimova ${ }^{2} \dagger$ \\ ${ }^{1}$ Belarusian State University, Department of English for Economics, Minsk, Belarus \\ ${ }^{2}$ Financial University under the Government of the Russian Federation, Department of Foreign \\ Languages and Intercultural Communication, Moscow, Russia \\ ${ }^{3}$ Copenhagen Business School, Department of International Economics, Government and Business, \\ Copenhagen, Denmark
}

\begin{abstract}
Effective business communication requires a certain degree of cross-cultural awareness and tolerance both on the ethnic and organizational levels. Communication patterns vary from culture to culture according to values, beliefs and traditional rules for interacting with others, which makes up a learned behavior. These deep-rooted factors lie inside cultural differences and change very slowly if ever as compared to those which are more likely to be on the surface, like food, tastes, art. The latter are more easily adopted or erased in today's global economy. The purpose of the study is to show that the internal traits compose different layers of metaphoricity in the language and, if understated, may lead to complexities or failures in business communication. Based on the experience of working in an international environment, which is analyzed by many scientists, and on the results of the study performed it can be noted that cross-cultural awareness and tolerance imply a variety of intelligences beyond (IQ), including emotional, cultural, social, and collective types of intelligence.

Keywords: collective intelligence, communication patterns, metaphoricity
\end{abstract}

\section{Introduction}

In a geographically structured organization, where divisions are represented by geography or country, understanding cultural complexities is critical to business success. The assumption as to the importance of fundamental cultural values in effective business communication lies on the intense studies in the field which have brought about ample information regarding the importance of cultural awareness in business communication. The role of cultural factors either in success or failure in doing business internationally is the subject of the current study. Such deep components of culture as values, beliefs, cognitive styles, relationship with the environment, attitude to social structure, time and

\footnotetext{
* Corresponding author: svetlanadubinko@gmail.com

† Died July 25, 2021.
} 
communication patterns change very slowly or do not change at all, even in our global world. Values and beliefs are a key issue in understanding cultural differences. Their impact on the corporate climate within multinational companies is the object of the article. Most organizations have a vision and values that define their organizational culture. The vision and values provide a common foundation for the entire organization. They communicate what the organization is and how employees should conduct business and interact with each other and with the customers. They set the tone for behavioral and operational expectations. The hypothesis of the study based on the previous assumption implies that the process of globalization and the desire of multinational companies to standardize procedures will lead to some convergence between individualistic and collectivistic cultures in terms of organizational structure, which will lead to erasing some differences in cultural patterns in business communication, but the difference in deep-rooted values and worldviews will preserve organizational diversity for many years to come.

Based on the experience of working in an international environment, which is analyzed in the works published by many scientists, it can be noted that cross-cultural awareness and tolerance imply a variety of intelligences, including emotional, cultural, social, and collective types of intelligence [1-8].

The fundamental values of each culture are linked to the metaphorical structure of the most fundamental concepts of the language. Some values are deeply rooted in different cultures. The study of the levels of metaphoricity can significantly increase our competence regarding the communicative specifics of this or that culture.

\subsection{Cultural traditions in the process of globalization}

In today's global economy understanding cultural differences can make you successful in building business relationships and running business, while failing to recognize these differences can lead to misunderstandings, destroy business relationships, and damage billions of dollars' worth of transactions [9-13]. How do organizational, national, and ethnic values coexist? It is known that socially desirable, organizational values do not necessarily fully correspond to national or ethnic values [3, 14-19]. There may be some overlap, especially in the area of personal behavior towards other employees, but there are also certain differences. For example, the thesis "avoid conflicts, treat others with respect and dignity" seems quite harmless. However, ethnically, this can be interpreted in very different ways. It may suggest differences in such communicative behavioral tactics as directness and indirectness inherent in linear-active and multi-active cultures. To the members of the latter, American directness may seem offensive or even aggressive, while their linearly active partners may view indirection in business as insincere behavior that can destroy trust and lead to communication failure. Cultures vary in their egalitarian or authoritarian orientation; differ in building personal relationships and understanding their role in doing business.

In order to identify the value picture that is most favorable for building business relationships, it is necessary to compare socially desirable, organizational values and national, ethnic values inherent in representatives of this or that culture. The comparison, in our opinion, is possible and convenient to present on the basis of the main value orientations, for example, those presented in E. Hall's and G. Hofstede's scales. It should take into account the tasks assigned to the company and the complexity of its organization, including the cross-cultural factor of communication [9, 11, 20-22].

Can a large multinational organization have its own particular culture and spread it throughout its national branch? Multinational corporations are interested in promoting a 
common culture in their subsidiaries, because it is seen as a kind of connecting material that should help achieve integration and coordination [23]. However, subsidiaries often have an ingrained national culture that can resist what the headquarters would like to impose. This means that national values sometimes exceed corporate values. Citing research results, $\mathrm{N}$. Adler clearly dispels the myth that corporate culture can erase national culture [24]. J. Hofstede, F. Trompenaars and other leading experts share the same opinion [21, 25]. If an organization is redefining and re-evaluating its values as a result of a new business strategy or leadership team, this is a great opportunity to learn from employees and their contributions-especially global contributions. From this point of view, collective intelligence is of particular importance as a form of universal, distributed intelligence resulting from the cooperation and competition of many individuals. Collective intelligence manifests itself in the areas of organizational behavior and leadership. Many organizations discover collective intelligence and put it into practice to classify, evaluate, and share information, as well as to make forecasts and solve problems [2, 18]. It seems that the increasing role of collective intelligence will be manifested not only in the choice of the company's business strategy, but also in the format of cross-cultural communication in order to find the most acceptable balance between organizational and ethnic values to achieve more effective results of the chosen business strategy.

\subsection{Metaphorical Aspect of Business Communication}

The linguistic metaphor is considered as a phenomenon that is secondary to the conceptual metaphor embedded in the conceptual system of a person and reflects his perception, thinking and activity [26]. A detailed classification of metaphors is presented in the works of G. Lakoff, M. Johnson, and M. Turner [26, 27].

The fundamental values of each culture are linked to the metaphorical structure of the most fundamental concepts and values. We talk in terms of metaphor in everyday life and business communication: we win or lose arguments, defend or lose our position and attack someone's point of view. A lot of what we do is structured with basic conceptual metaphors (like war / peace, etc.). And although there is no battle in the direct physical sense of the word, it is essentially transferred to the field of verbal battle [65]. Our logical arguments, direct or indirect tactics of speech behavior with the help of appropriate metaphors fixed in the cognitive base of a particular culture, reflect this: 'The discussion fell to the emotional level, but we raised it back up to the rational plane', 'The argument is shaky', The argument collapsed', The theory has no foundation', 'Let's gain an insight into the problem', 'Current work along these lines intends to shed some light on this issue" 'Your argument won't hold water'.

In texts of an economic nature, we observe a wide application of metaphors that appeal to such conceptual issues in our daily life as time, movement, space, etc. So, money, financial affairs are often associated with liquid: 'After the merger, the new company will be able to attract new sources of resources', 'As new interest rates are high, money is flowing into Germany', 'There is a constant ebb and flow of money in and out of the system', 'Banks have been on the crest of a wave for much longer than anyone expected'. The following example metaphorically uses the concept of "time" in business: "Look, we've put a lot of money and effort into this project. We can't retreat now." A lot of metaphorical expressions refer particularly to money (spend, invest, budget, profitably, cost) or to limited resources (use up, have enough of, run out of) [26].

Metaphors reflect cultural coherence in the attitude to the concept of future. In the Western world, particularly in the United States, people tend to think of time as something 
fixed in nature, something from which one cannot escape: one thing at a time. This is the core issue in monochromic cultures. People who cannot plan events are not highly regarded. The word 'future' is used with the definite article in American English: 'in the future'. The American idea of the future is limited and shows the foreseeable future ('All upcoming events are listed in the paper', What's coming up this week?', 'I'm afraid of what's up ahead of us'). These different approaches to time and the idea of future show the difference in approaches to business appointments, agenda, contract, long-term and short-term planning, and deadlines.

The study of the levels of metaphoricity could significantly increase our competence regarding the communicative specifics of this culture, as well as shed light on the features of the conceptual structure of the English discourse [4, 28-30].

\section{Methods}

\subsection{Study area and sample selection}

The study employed a mixed-methods research design (quantitative - qualitative). The survey was conducted among the fourth-year students of the specialty "World economy" of the Belarusian State University, Faculty of International Relations in two stages: Part A and Part B. Part A was performed by the students after completing the theoretical course on intercultural communication, while Part B presupposed the application of students' practical skills in this area after completing a practical course of training in firms and companies working with their foreign counterparts for three months.

\subsection{Questionnaire design and data collection}

26 respondents participated in Part A, and 28 respondents - in Part B of the experiment. The response rate was $86.7 \%$, or 26 out of 30 people for Part A, $93.3 \%$ or 28 out of 30 people for Part B. The majority of the respondents participating in part A $(92.3 \%)$ were 23 years old, $7.7 \%$ of the participants were 22 years old at the time of the survey. $91.7 \%$ of the respondents in Part B were 23 years old, 8.3\% were 22 years old. In the gender ratio, $82.2 \%$ of the respondents were women and $17.8 \%$ - men in Part A. Part B was represented by $74.5 \%$ of women, $25.5 \%$ - men. The participation of the respondents was completely voluntary. A cross-sectional survey questionnaire method was used to collect the required data. Two sets of tasks (one set for each part) were offered: a set of proverbs and a set of statements which reflect different cultural values as far as attitude to time, punctuality, deadlines, being-oriented or doing-oriented character of life are concerned.

Part A was aimed at evaluating the suggested proverbs and sayings in terms of cultural meanings and their accompanying behavioral patterns as individualistic or collectivistic norms, "both" or "puzzled", using the theoretical basis of the study course on intercultural communication.

The task in Part B was to relate this list of proverbs and statements to the students' cultural values and assumptions as "yes", 'no" or 'puzzled'. This task was given to the students after completing the course of practical training in multinational firms and companies working with their foreign counterparts. The answers were chosen for the analysis according to their predominance: those which had more than 50\% (Table 1, Table 2). The survey was conducted by a research assistant anonymously in the Google forms application in the classroom. The data were collected using a questionnaire developed in 
English. The questionnaires were personally distributed by the researcher, and the respondents were made aware of their rights to withdraw their participation at any time during the study.

C. Data analysis

The results of the study were presented using descriptive statistics.

Table 1. Stage A. Before completing the course of practical training in multinational firms and companies.

\begin{tabular}{|c|c|c|c|c|c|c|}
\hline \multirow[b]{2}{*}{ Proverbs } & \multicolumn{4}{|c|}{ Question 1} & \multicolumn{2}{|c|}{$\begin{array}{l}\text { Question } \\
2\end{array}$} \\
\hline & $\begin{array}{l}\text { Ind.* } \\
, \%\end{array}$ & $\begin{array}{l}\text { Col.**, } \\
\%\end{array}$ & $\begin{array}{l}\text { Both, } \\
\%\end{array}$ & $\begin{array}{l}\text { Puzzled, } \\
\%\end{array}$ & $\begin{array}{l}\text { Yes, } \\
\%\end{array}$ & $\begin{array}{l}\text { No, } \\
\%\end{array}$ \\
\hline 1. Cleanliness is next to godliness & 32 & 67 & $\leq 1$ & $\leq 1$ & 64.3 & 35.7 \\
\hline 2. God helps those who help themselves & 87 & 12 & $\leq 1$ & $\leq 1$ & 74.3 & 25.7 \\
\hline 3. A penny saved is a penny earned & \multicolumn{2}{|r|}{7} & 92 & $\leq 1$ & 74.7 & 25.3 \\
\hline 4. A man's home is his castle & 95 & 4 & $\leq 1$ & $\leq 1$ & 6.4 & 93.6 \\
\hline 5. Actions speak louder than words & 74 & 25 & $\leq 1$ & $\leq 1$ & 83.6 & 16.4 \\
\hline $\begin{array}{l}\text { 6. It's not whether you win or lose but how you } \\
\text { play the game }\end{array}$ & 35 & 64 & $\leq 1$ & $\leq 1$ & 68.5 & 31.5 \\
\hline $\begin{array}{l}\text { 7. Winning isn't everything; winning is the only } \\
\text { thing }\end{array}$ & 97 & 2 & $\leq 1$ & $\leq 1$ & 24.7 & 75.3 \\
\hline 8. Seeing is believing & \multicolumn{3}{|c|}{37} & 62 & 76.8 & 23.2 \\
\hline 9. Time is money & \multicolumn{2}{|c|}{15} & 84 & $\leq 1$ & 62.8 & 37.2 \\
\hline 10. Better late than never & 32 & 67 & $\leq 1$ & $\leq 1$ & 87.8 & 12.2 \\
\hline \multicolumn{7}{|l|}{ Statements } \\
\hline 1. Everyone should have an equal chance & 98.7 & 1.3 & $\leq 1$ & $\leq 1$ & 78 & 22 \\
\hline $\begin{array}{l}\text { 2. Group improvement is better than } \\
\text { self-improvement; indeed, self-improvement is } \\
\text { achieved through group improvement }\end{array}$ & 24.2 & 75.8 & $\leq 1$ & $\leq 1$ & 87.6 & 12.4 \\
\hline 3. Everyone needs breathing room & 87.8 & 12.2 & $\leq 1$ & $\leq 1$ & 94.7 & 5.3 \\
\hline $\begin{array}{l}\text { 4. There is a solution to every problem; we just } \\
\text { haven't invented it yet }\end{array}$ & 75.8 & 24.2 & $\leq 1$ & $\leq 1$ & 36.7 & 63.3 \\
\hline
\end{tabular}




\begin{tabular}{|l|c|c|c|c|c|c|}
\hline 5. Life is a lottery; it can be won with a little luck & 26.2 & 73.8 & $\leq 1$ & $\leq 1$ & 86.7 & 13.3 \\
\hline $\begin{array}{l}\text { 6. One shouldn't mix business with pleasure. After } \\
\text { all, life is short }\end{array}$ & \multicolumn{2}{|c|}{12.6} & 87.4 & $\leq 1$ & 65.4 & 34.6 \\
\hline $\begin{array}{l}\text { 7. The individual in a group is more important than } \\
\text { the group }\end{array}$ & 96.5 & 3.5 & $\leq 1$ & $\leq 1$ & 35.2 & 64.8 \\
\hline $\begin{array}{l}\text { 8. You shouldn't worry about the past or the future; } \\
\text { the present is what really counts }\end{array}$ & 25.6 & 74.4 & $\leq 1$ & $\leq 1$ & 84.7 & 15.3 \\
\hline $\begin{array}{l}\text { 9. You're as young as you act } \\
\text { 10. The sky's the limit; you can do anything you } \\
\text { wish if you just try }\end{array}$ & 78.6 & 21.4 & $\leq 1$ & $\leq 1$ & 76.8 & 23.2 \\
\hline
\end{tabular}

Table 2. Stage B. After completing the course of practical training in multinational firms and companies $\leq 1$.

\begin{tabular}{|c|c|c|c|c|c|c|}
\hline \multirow[b]{2}{*}{ Proverbs } & \multicolumn{4}{|c|}{ Question 1} & \multicolumn{2}{|c|}{$\begin{array}{l}\text { Question } \\
2\end{array}$} \\
\hline & $\begin{array}{l}\text { Ind., } \\
\%\end{array}$ & $\begin{array}{l}\text { Col., } \\
\%\end{array}$ & $\begin{array}{l}\text { Both, } \\
\%\end{array}$ & $\begin{array}{l}\text { Puzzled, } \\
\%\end{array}$ & $\begin{array}{l}\text { Yes, } \\
\%\end{array}$ & $\begin{array}{l}\text { No, } \\
\%\end{array}$ \\
\hline 1. Cleanliness is next to godliness & 32 & 67 & $\leq 1$ & $\leq 1$ & 64.3 & 35.7 \\
\hline 2. God helps those who help themselves & 87 & 12 & $\leq 1$ & $\leq 1$ & 74.3 & 25.7 \\
\hline 3. A penny saved is a penny earned & \multicolumn{2}{|r|}{7} & 92 & $\leq 1$ & 74.7 & 25.3 \\
\hline 4. A man's home is his castle & 95 & 4 & $\leq 1$ & $\leq 1$ & 76.2 & 23.8 \\
\hline 5. Actions speak louder than words & 74 & 25 & $\leq 1$ & $\leq 1$ & 83.6 & 16.4 \\
\hline $\begin{array}{l}\text { 6. It's not whether you win or lose but how you } \\
\text { play the game }\end{array}$ & 35 & 64 & $\leq 1$ & $\leq 1$ & 26.8 & 73.2 \\
\hline $\begin{array}{l}\text { 7. Winning isn't everything; winning is the only } \\
\text { thing }\end{array}$ & 97 & 2 & $\leq 1$ & $\leq 1$ & 64.4 & 35.6 \\
\hline 8. Seeing is believing & 73 & 26 & $\leq 1$ & $\leq 1$ & 76.8 & 23.2 \\
\hline 9. Time is money & \multicolumn{2}{|c|}{15} & 84 & $\leq 1$ & 62.8 & 37.2 \\
\hline 10. Better late than never & 32 & 67 & $\leq 1$ & $\leq 1$ & 87.8 & 12.2 \\
\hline \multicolumn{7}{|l|}{ Statements } \\
\hline 1. Everyone should have an equal chance & 98.7 & 1.3 & $\leq 1$ & $\leq 1$ & 78 & 22 \\
\hline
\end{tabular}




\begin{tabular}{|c|c|c|c|c|c|c|}
\hline $\begin{array}{l}\text { 2. Group improvement is better than } \\
\text { self-improvement; indeed, self-improvement is } \\
\text { achieved through group improvement }\end{array}$ & 24.2 & 75.8 & $\leq 1$ & $\leq 1$ & 36.7 & 63.3 \\
\hline 3. Everyone needs breathing room & 87.8 & 12.2 & $\leq 1$ & $\leq 1$ & 94.7 & 5.3 \\
\hline $\begin{array}{l}\text { 4. There is a solution to every problem; we just } \\
\text { haven't invented it yet }\end{array}$ & 75.8 & 24.2 & $\leq 1$ & $\leq 1$ & 31.8 & 68.2 \\
\hline 5. Life is a lottery; it can be won with a little luck & 26.2 & 73.8 & $\leq 1$ & $\leq 1$ & 86.7 & 13.3 \\
\hline $\begin{array}{l}\text { 6. One shouldn't mix business with pleasure. After } \\
\text { all, life is short }\end{array}$ & \multicolumn{2}{|c|}{12.6} & 87.4 & $\leq 1$ & 65.4 & 34.6 \\
\hline $\begin{array}{l}\text { 7. The individual in a group is more important than } \\
\text { the group }\end{array}$ & 96.5 & 3.5 & $\leq 1$ & $\leq 1$ & 35.2 & 64.8 \\
\hline $\begin{array}{l}\text { 8. You shouldn't worry about the past or the } \\
\text { future; the present is what really counts }\end{array}$ & 25.6 & 74.4 & $\leq 1$ & $\leq 1$ & 84.7 & 72.8 \\
\hline 9. You're as young as you act & 67.8 & 32.2 & $\leq 1$ & $\leq 1$ & 77.4 & 22.6 \\
\hline $\begin{array}{l}\text { 10. The sky's the limit; you can do anything you } \\
\text { wish if you just try }\end{array}$ & 78.6 & 21.4 & $\leq 1$ & $\leq 1$ & 76.8 & 23.2 \\
\hline
\end{tabular}

* Individualistic cultures

** Collectivistic cultures

\section{$3 \quad$ Results}

Part A. Proverbs 1, 6, 10 and statements 2, 5, 6, 8 in Part A were referred to collectivistic cultures by the majority of the respondents. Individualistic cultures were marked by points 2, 4, 5, 7 in proverbs and points $1,3,4,7,9,10$ in statements. Points 3, 9 in the list of proverbs and point 6- in the list of statements were qualified as belonging to both individualistic and collectivistic cultures, point 8 in the list of proverbs was marked as 'puzzled'. These points, as it appears, reflect the concepts which in our global world may be regarded as universal truths. The analysis of other data shows that the criteria which lie as the basis for differences reflected in the proverbs and statements determine the attitude to career and accomplishments, power distance, punctuality, efficiency, competition or social harmony, tendency to inductive or deductive thinking, the appropriate use of time in business communication. The analysis of students' belonging to this or that category according to their answers ('yes', 'no', 'both', 'puzzled') shows that $45 \%$ of the data analyzed go to the collectivistic patterns of behavior, $30 \%$ - to the individualistic ones, $15 \%$ to 'both' and $5 \%$ - to the category "puzzled'.

Part B. Points 1, 6, 10 in the list of proverbs and points 2, 5, 8 in the list of statements show the tendency towards collectivistic patterns. Answers in points 2, 4, 5, 7, 8 in the list of proverbs and those in points 1, 3, 4, 7, 9, 10 in the list of statements illustrate collectivistic behavior. Points 3, 9 among the proverbs and point 6 in the list of statements 
are regarded as 'both'. These points are more likely to reflect universal truths in business communication. The analysis of students' belonging to this or that category according to their answers ('yes', 'no', 'both', 'puzzled') shows that $20 \%$ of the data analyzed go to the collectivistic patterns of behavior, $65 \%$ - to the individualistic ones, $15 \%$ to 'both'.

\section{Discussion}

The analysis of the results obtained in Parts A and B shows a number of similarities and differences in theoretical understanding of categorizing cultures as individualistic and collectivistic ones before and after the students' completing a practical course of working with foreign counterparts in multinational companies as well as students' personal vision of their belonging to this or that cultural category. It may be noted that similarities embrace points $1,2,5,9,10$ in the list of proverbs and points $1,3,5,6,7,9,10$ - in the list of statements. It is worth mentioning that these points give the confirmation of students' understanding both the principles of categorizing cultures and their belonging to this or that category through the concepts expressed in proverbs and statements and their practical experience. The differences in the results of Part A and B of the experiment concern the student' change in their vision as belonging to the type of categories before and after the practical course due to the experience obtained while working with foreign counterparts which was a practical approbation of the theoretical principles of categorizing cultures. The students' answers in points 4, 6, 7, 8 in the list of proverbs and points 2, 4, 68 - in the list of sayings illustrate shifting from collectivistic to individualistic cultural patterns.

\section{Conclusion}

Judging by the results which show the similarities in the opinions as regards to the tasks in Part A and Part B the students position themselves as representatives of the individualistic cultures (answers in points 2 in the list of proverbs, 1, 3, 7, 9, 10 - in the list of statements) and as representatives of the collectivistic patterns (points 1, 10 in the list of proverbs and point 5 in the list of statements) both at stages A and B of the experiment. Points 9 (answers in the list of proverbs) and 6 in the list of statements are referred to the both cultural categories in Parts A and B of the study. Thus the concepts expressed in the latter may be qualified as universal truths. The differences in indices between stages A and B as far as students' vision of belonging to this or that category is concerned are due to practical experience and collective intelligence, which contributed to their assessment of internal values and beliefs in business communication.

The tendencies illustrated by the results of the study, in particular by the similarities and differences of the data in Parts A and B, show that there are some cultural patterns which may be the subject to changes in business communication and those behavioral norms which lie deep in the roots of the culture and remain unchanged. The study supports the previous assumption and the hypothesis that the process of globalization and the desire of multinational companies to standardize procedures will lead to some convergence between individualistic and collectivistic cultures in terms of organizational structure, but the difference in values and worldviews will preserve organizational diversity.

\section{References}


1. I. Alon, J.M. Higgins, Bus Horizons 48(6), 501-512 (2005).

https://doi.org/10.1016/j.bushor.2005.04.003

2. L.A. Dubinka-Hushcha, Augmenting collective intelligence through blended learning and open educational resources, in Intercultural Communication and Professionally Oriented Teaching Foreign Languages: materials of the 13th international scientific conf., Minsk, October 30, 2019, 105-109 (Belarusian State University, Minsk, 2019)

3. Y.Y. Kim, The International Encyclopedia of Intercultural Communication (Wiley-Blackwell, 2017). https://doi.org/10.1002/9781118783665

4. I.E. Klyukanov, Principles of Intercultural Communication (Routledge, 2021)

5. D. Livermore, Leading with cultural intelligence: The real secret to success. Second edition (AMACOM, 2015)

6. K. Mchugh, et al., The Leadership Quart, 27(2), 218-241 (2016). https://doi.org/10.1016/j.leaqua.2016.01.001

7. M.F. Peters, Open Re Edu Res, 2(1), 259-266 (2015). https://doi.org/10.1080/23265507.2015.1084477

8. E. Smith, Toward Internationalization (Newbury House, Rowles, 1979)

9. L. Chen, Intercultural Communication (Handbooks of Communication Science, 2017). https://doi.org/10.1515/9781501500060

10. S.M. Croucher, Global Perspectives on Intercultural Communication (Routledge, 2017)

11. G. Ferri, Intercultural Communication: Critical Approaches and Future Challenges (Springer International Publishing, 2018). https://doi.org/10.1007/978-3-319-73918-2

12. R.E. Nelson, S. ScGopalan, Org Stud, 24(7), 1115-1151 (2003). https://doi.org/10.1177/01708406030247006

13. K. Sorrells, S. Sachi, Globalizing Intercultural Communication : a Reader (SAGE Publications, Inc, 2016)

14. I. Adizes, Global Crisis as Leadership Challenge (Bled School of Management, Bled, 2020)

15. N.V. Baryshnikov, Plyuralisticheskaya didaktika yazykov i kultur [Pluralistic didactics of languages and cultures], in Linguodidactic Problems of the Formation of Foreign Language Competencies: Collective Monograph Based on the Materials of the International Scientific and Methodological Symposium "Lempert Readings XIX", 16-22 (PSU Publishing House, Pyatigorsk, 2017)

16. X. Dai, Ch. Guo-Ming, Conflict Management and Intercultural Communication: The Art of Intercultural Harmony (Routledge, 2017)

17. M.D. Hills, Online Read Psy Cult, 4(4) (2002). https://doi.org/10.9707/2307-0919.1040

18. I. Klimova, G. Klimova, S. Dubinka, XLinguae, 12(1), 207-218 (2019)

19. J. Santos, Globalisation is Dead. Long Live Globalisation! (Bled School of Management, 2017)

20. E.T. Hall, The Hidden Dimension (Anchor Books, 1969)

21. G. Hofstede, Culture's consequences. Comparing values, behaviors, institutions, and organizations across nations (Sage, Thousand Oaks, 2001)

22. S. Schwartz, Chapter 7 A Proposal for Measuring Value Orientations across Nations (2007) 
23. S.C. Schneider, Human Res Manag, 27(2), 231-246 (1988). https://doi.org/10.1002/hrm.3930270207

24. N.J. Adler, International dimensions of organizational behavior (South-Western, Cincinnati, 1977)

25. Ch Hampden-Turner, F. Trompenaars, Group \& Organization Management, 31(1), 56-63 (2006). doi:10.1177/1059601105276942

26. G. Lakoff, M. Johnson, Metaphors we live by (The University of Chicago Press, Chicago, London, 2003)

27. M. Turner, The literary mind (Oxford University Press, New York, 1996)

28. Research Methods in Intercultural Communication a Practical Guide (Wiley Blackwell, 2016)

29. G.J. Steen, Attention to metaphor: where embodied cognition and social interaction can meet, but may not often do so (Cambridge University Press, 2017)

30. 57 Metaphor Examples That'll Pack Your Prose with Persuasion (2021). Accessed on: September 24, 2021. [Online]. Available:

https://smartblogger.com/metaphor-examples/ 